\title{
The Impact of Organizational Justice on Turnover Intention of Bankers of KPK, Pakistan: The Mediator Role of Organizational Commitment
}

\author{
Norhani Bakri ${ }^{1} \&$ Nazim $\mathrm{Ali}^{1}$ \\ ${ }^{1}$ Faculty of Management, Universiti Teknologi Malaysia, Malaysia \\ Correspondence: Nazim Ali, Faculty of Management, Universiti Teknologi Malaysia, Malaysia. E-mail: \\ nazimali1000@gmail.com
}

Received: April 21, 2015 Accepted: May 18, 2015 Online Published: July 6, 2015

doi:10.5539/ass.v11n21p143 URL: http://dx.doi.org/10.5539/ass.v11n21p143

\begin{abstract}
The main purpose of this research was to investigate the mediating effect of organizational commitment between organizational justice and turnover Intention of bankers, Pakistan. Data were collected through organizational commitment questionnaire, organizational justice questionnaire and turnover Intention questionnaire from 177 bankers of KPK, Pakistan. Results showed that organizational justice had a significant positive relationship with organizational commitment and negative relationship with turnover Intention. It was also found that organizational commitment had a significant negative relationship with turnover Intention. Confirmatory factor analysis explored that the measurement model of organizational justice, organizational commitment and turnover Intention fit the sample data very well. Organizational justice showed a direct impact of - 68 on turnover Intention. The impact of organizational justice on turnover Intention came down to $-22 \%$ when organizational commitment as mediator was included. Organizational commitment mediated the role between organizational justice and turnover Intention. Furthermore, OJ showed a significant impact of $68 \%$ on organizational commitment that led to $-72 \%$ impact on turnover Intention.
\end{abstract}

Keywords: organizational commitment, organizational justice, turnover intention, bankers, Pakistan

\section{Introduction}

Banks are service sector organizations whose employees are playing very important role in the accomplishment of the predetermined goals. Most of the time performances are associated with organizational justice (OJ). Greenberg (1990) says that "social scientists have long recognized the importance of the ideals of justice as a basic requirement for the effective functioning of organizations and the personal satisfaction of the individuals they employ." OJ describes the individuals' (or groups') perception of the fairness of treatment received from an organization and their behavioral reaction to such perceptions (James, 1993). OJ has three dimensions which are distributive justice (DJ), procedural justice (PJ) and interactional justice (IJ) (Martinez-tur et al., 2006). DJ is referred to as "the fairness of outcomes an employee receives such as pay and promotions" (Moorman, 1991). PJ is "the fairness of the procedures used in determining employee outcomes" (Moorman, 1991), whereas IJ is "the interpersonal treatment employees receive from decision makers and the adequacy with which the formal decision-making procedures are explained" (Greenberg, 1990). The primary focus of the OJ is about the fairness at workplace and it has a bearing on the attitudes of employees like job satisfaction, turnover intention (TI), absenteeism, role breadth, job performance, leadership and Organizational Commitment (OC), leader-member exchange and trust (Bakhshi, 2009; Boer et al., 2002; Byrne, 2005; Colquitt, 2001; Greenberg, 2004; Hubbel \& Chory-Assad, 2005; Judge \& Colquitt, 2004; Lambert, Hogan, \& Griffin, 2007; Vermunt \& Steensma, 2003; Wat \& Shaffer, 2005)

In the management literature $\mathrm{OC}$ is an important aspect. A sense of loyalty with the organization and aligning with the goals of the organization and giving value to these goals is all about OC (Fang, 2001; Lambert et al., 2007). OC has three dimensions which are affective commitment, continuance commimtnet and normative commitment. Kanter (1968) defines affective commitment as"the attachement of an individual's fund of affectivity and emotion to the group". Buchanan (1974) says that affective commitment is "partisan, affective attachemnent to the goals and values, and to the organization for its own sake, apart from its purely instrumental 
worth". Similarly, Mowday et al., (1979) describe affective commitment as "the relative strength of an individual's identification and involvement in a particular organization". Continuation commitment refers to the "profit associated with continued participation and 'cost' associated with leaving" Kanter (1968). Likewise, Stebbins (1970) describes continuance commitment as the awareness of the impossibility of choosing a different social identity ... because of the immense panalties involved in making the switch". Normative commitment, also known as the 'Sense of Obligation to Stay', refers to the commitment that is based on moral obligation and belief that "it is the right and moral thing" not to quit the organization.

Price (2001) defines turnover as the "individual movement across the membership boundary of an organization". The intention of quitting the current job and removal of organizational membership is called TI (Meyer \& Allen, 1984). High turnover rate (calculated as: number of employees who have quit the organization during a year / total number of employees during a year * 100) is very baleful for the organization in the form of direct and indirect cost. An organization has to spend millions of dollars on advertisement, recruitment, selection, induction, orientation, and training and development of newly hired employees when turnover rate is high.

We found only two studies on the relationship between OJ and TI of bankers. Saeidi, et al., (2013) collected data from bankers of mellat bank of Golestan Province, Iran and tested the relationship between OJ and TI. They found a significant negative relationship between OJ and TI. Hassan (2002) collected data from 181 middle and lower level managers of the banking, finance, production, manufacturing, and service sector and concluded that internal and external equity contributed to increased commitment and decreased intent to leave.

The present study was conducted for a few reasons. First, there is a paucity of research to investigate the relationship between OJ and TI of bankers. Second, no study has ever been conducted to explore the mediating effect of OC between OJ and TI. Third, the studies of Molaeifaret al., (2013) and Hussan (2002) used correlation and regression to test the relationship between OJ and TI of bankers while in the current study I used confirmatory factor analysis and tested every individual model and a combine model of all the three variables which were OJ, OC and TI.

\section{Methods}

\subsection{Data Collection}

Data were collected through questionnaire from one hundred and seventy seven (177) employees of Officer Grade I, II and III working in private sector banks of KPK Province, Pakistan. We visited thirty (30) branch managers and informed them about the study and its benefits for the organization. They were requested to give us 20 minutes to discuss with employees the purpose of the study and data collection from them through questionnaire. The managers agreed and I physically distributed the questionnaires to the employees of thirty branches. First I took five minutes to inform the employees of the purpose of the research and then distributed the questionnaires. It took almost 15 minutes to complete and return the completed questionnaire.

\subsection{Measurement}

\subsubsection{Organizational Justice Questionnaire}

OJ questionnaire was adapted from by Price and Mueller (1986) to measure DJ, PJ and IJ. DJ has five (5) items, PJ six (6) items and IJ nine (9) items. In this study, all justices were measured by four (4) items each. The reason for choosing only four (4) items for each type of justice was to save the time of respondents. 7 point likert scale ranging from 1 "strongly disagree" to 7 "strongly agree" was used to elicit the responses of participants.

\subsubsection{Organizational Commitment Questionnaire}

Affective, continuance and normative commitment were measured by Meyer et al's (1993) six-item versions of the scales. Each dimension of OC has six items. Responses were elicited by using 7-point likert scale ranging from 1 "Strongly Disagree" to 7 "Strongly Agree".

\subsubsection{Turnover Intention Questionnaire}

Three items from Michigan Organization Assessment Questionnaire (Cammann, Fichman, Jenkins, and Klesh, 1979) were adapted to measure TI of bankers. Responses were elicited by using 5-point likert scale ranging from 1 "Strongly Disagree" to 5 "Strongly Agree".

\section{Results}

Table 1 showed that OJ had a significant positive relationship with OC and negative relationship with TI. It was also found that OC had a significant negative relationship with TI. 
Table 1. Relationship between OJ, OC and TI

\begin{tabular}{cccc}
\hline & OJ & OC & TI \\
\hline OJ & 1 & $.380^{* *}$ & $-.494^{* *}$ \\
OC & $.380^{* *}$ & 1 & $-.554^{* *}$ \\
TI & $-.494^{* *}$ & $-.554^{* *}$ & 1 \\
\hline
\end{tabular}

Mode1

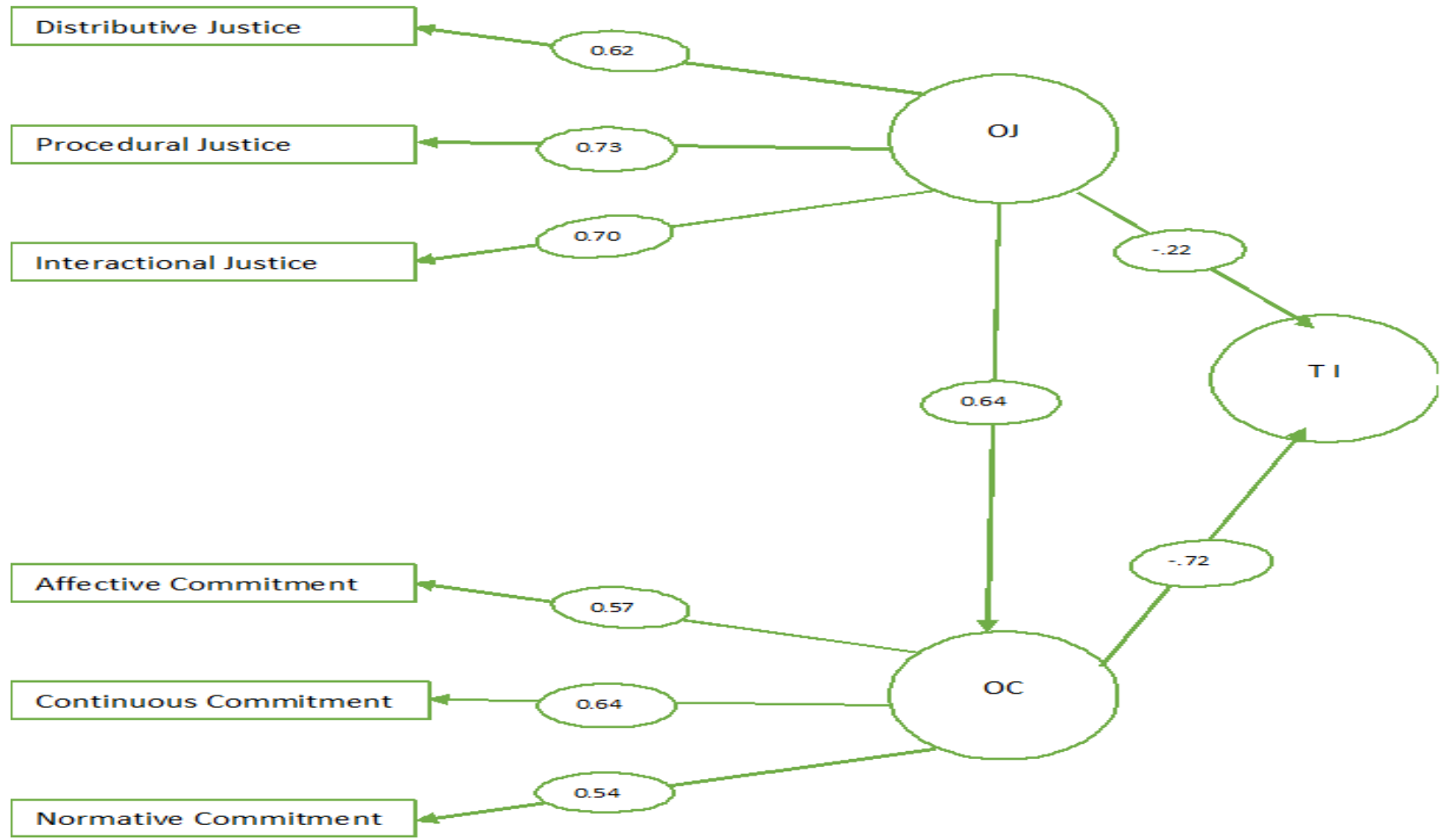

Confirmatory factor analysis (CFA) explored that all the individual models of OC, OJ and TI fit the sample data very well. For $\mathrm{OC}$ : Chi square $(\mathrm{N}=177)=155.543, \mathrm{df}=132, \mathrm{p}<0.079 ; \mathrm{GFI}=0.919 ; \mathrm{CFI}=0.988$; $\mathrm{SRMR}=$ 0.092 and RMSEA $=0.031$. For OJ: Chi square $(\mathrm{N}=177)=83.201, \mathrm{df}=51, \mathrm{p}<0.003 ; \mathrm{GFI}=0.929 ; \mathrm{CFI}=0.968$; $\mathrm{SRMR}=0.077$ and RMSEA $=0.060$. For TI after applying 1 as additional constraint: Chi square $(\mathrm{N}=177)=$ $0.889, \mathrm{df}=1, \mathrm{p}<0.046 ; \mathrm{GFI}=0.997 ; \mathrm{CFI}=1 ; \mathrm{SRMR}=0.027$ and RMSEA $=0.000$. For OJ and TI: Chi square $(\mathrm{N}$ $=177)=132.22, \mathrm{df}=86, \mathrm{p}<0.001 ; \mathrm{GFI}=0.911 ; \mathrm{CFI}=0.961 ; \mathrm{SRMR}=0.080$ and RMSEA $=0.055$. OJ showed a direct impact of $-68 \%$ on TI.

Confirmatory factor analysis (CFA) also explored that the measurement model of OJ, OC and TI fit the sample data very well. Chi square $(\mathrm{N}=177)=589.804, \mathrm{df}=486, \mathrm{p}<0.001 ; \mathrm{GFI}=0.944 ; \mathrm{CFI}=0.967 ; \mathrm{SRMR}=0.063$ and RMSEA $=0.035$. OJ showed an indirect impact of $-22 \%$ on TI when OC as mediator was included. OC mediated the role between OJ and TI. Furthermore, OJ showed a significant impact of $68 \%$ on OC that led to $-72 \%$ impact on TI.

\section{Conclusion and Recommendation}

The basic aim of this study was to test the mediating effect of OC between OJ and TI of employees working in private sector banks of KPK, Pakistan. Data were collected through questionnaires from 177 bankers. Results showed that OJ had a significant positive relationship with OC and negative relationship with TI. It was also found that OC had a significant negative relationship with TI. Confirmatory factor analysis (CFA) explored that the measurement model of OJ, OC and TI fit the sample data very well. OJ showed a direct impact of -68 on TI. The impact of OJ on TI came down to $-22 \%$ when OC as mediator was included. OC mediated the role between OJ and TI. Furthermore, OJ showed a significant impact of $68 \%$ on OC that led to $-72 \%$ impact on TI. 
The management of private sector banks are requested to reduce turnover rate of bankers by increasing distributive, procedural and IJ practices because OJ showed a significant negative relationship with TI. The management should also consider OC because it mediated the relationship between OJ and TI. The current study may be repeated to test the mediating effect of OC between OJ and TI be taking sample from public sector banks of Pakistan or any other country.

\section{References}

Bakhshi, A. K. K., \& Rani, E. (2009). OJ perceptions as predictor of job satisfaction and OC. International Journal of Business and Management, 4(9), 145-154. http://dx.doi.org/10.5539/ijbm.v4n9p145

Boer, E. M. D., Bakker, A. B., Syroit, J. E., \& Schaufeli, W. B. (2002). Unfairness at work as a predictor of absenteeism. Journal of Organizational Behavior, 23, 181-197. http://dx.doi.org/10.1002/job.135

Buchanan, B. (1974). Building OC: The Socialization of Managers in Work Organizations. Administrative Science Quarterly, 19, 533-546. http://dx.doi.org/10.2307/2391809

Byrne, Z. S. (2005). Fairness reduces the negative effects of organizational politics on TIs, citizenship behavior and job performance. Journal of Business and Psychology, 20(2), 175-200. http://dx.doi.org/10.2307/ 2391809

Colquitt, J. A. (2001). On the dimensionality of OJ. A construct validation of a measure. Journal of Applied Psychology, 86, 386-400. http://dx.doi.org/10.1037/0021-9010.86.3.386

Fang, Y. (2001). Turnover propensity and its causes among Singapore nurses, an empirical study. International Journal of Human Resource Management, 12(5), 859-871. http://dx.doi.org/10.1080/713769669

Greenberg, J. (1990). Looking Fair Being Fair: managing Impressions of OJ. Research in Organizational Behavior, 12, 57-111.

Greenberg, J. (2004). Stress Fairness to Fare No Stress: Managing Workplace Stress by Promoting OJ. Organizational Dynamics, 33(4), 352-365. http://dx.doi.org/10.1016/j.orgdyn.2004.09.003

Hassan, A. (2002). OJ as a Determinant of OC and Intention to Leave. Asian Academy of Management Journal, $7(2), 55-66$.

Hubbel, A. P., \& Chory-Assad, R. M. (2005). Motivating Factors: Perceptions of Justice and Their Relationship with Managerial and Organizational Trust. Communication Studies, 56(1), 47-70. http://dx.doi.org/10.1080/ 0008957042000332241

James, K. (1993). The social context of OJ: cultural, intergroup and structural effects on justice behaviors and perceptions. In R. Cropanzano (Ed.), Justice in the Workplace: Approaching Fairness in Human Resource Management (pp. 21-50).

Judge, T. A., \& Colquitt, J. A. (2004). OJ and Stress: The Mediating Role of Work-Family Conflict. Journal of Applied Psychology, 89(3), 395-404. http://dx.doi.org/10.1037/0021-9010.89.3.395

Kanter, R. M. (1968). Commitment and social organization: A study of commitment mechanisms in Utopian communities. American Sociological Review, 33, 499-517. http://dx.doi.org/10.2307/2092438

Lambert, E. G., Hogan, N. L., \& Griffin, M. L. (2007). The impact of distributive and PJ on correctional staff job stress, job satisfaction, and OC. Journal of Criminal Justice, 35, 644-656. http://dx.doi.org/10.1016/j.jcrimjus.2007.09.001

Martínez-tur, V., Peiró, J. M., Ramos, J., \& Moliner, C. (2006). Justice perceptions as predictors of customer satisfaction: the impact of distributive, procedural, and IJ. Journal of Applied Social Psychology, 36, 100-119. http://dx.doi.org/10.1111/j.0021-9029.2006.00005.x

Meyer, J. P., \& Allen, N. J. (1984). Testing the side-bet theory of OC:some methodological considerations. Journal of Applied Psychology, 69(3), 372-378. http://dx.doi.org/10.1037/0021-9010.69.3.372

Molaeifar, H. R., Aghaei, A., \& Saeidi, P. (2013). An Investigation Relationship between OJ and Organizational Citizenship Behavior, and Intent to Leave Job. International Journal of Basic Sciences \& Applied Research, 2(3), 257-260.

Moorman, R. H. (1991). Relationship between OJ and Organizational Citizenship Behavior: Do fairness perceptions influence employee Citizenship? Journal of Applied Psychology, 76, 845-855. http://dx.doi.org/10.1037/0021-9010.76.6.845

Mowday, R., Steers, R., \& Porter, L. (1979). The measurement of organizational commitment. Journal of 
Vocational Behavior, 14, 224-247. http://dx.doi.org/10.1016/0001-8791(79)90072-1

Price, J. (2001). Reflections on the Determinants of Voluntary Turnover. International Journal of Manpower, 22, 600-624. http://dx.doi.org/10.1108/EUM0000000006233

Stebbins, R. A. (1970). On misunderstanding the concept of commitment: A theoretical clarification. Social Forces, 48, 526-529. http://dx.doi.org/10.1108/EUM0000000006233

Vermunt, R., \& Steensma, H. (2003). Physiological Relaxation: Stress Reduction Through Fair Treatment. Social Justice Research, 16(2), 135-149. http://dx.doi.org/10.1023/A:1024200120646

Wat, D. d., \& Shaffer, M. A. (2005). Equity and relationship quality influences on organizational citizenship behavior. Personnel Review, 34(4), 406-422. http://dx.doi.org/10.1108/00483480510599752

\section{Copyrights}

Copyright for this article is retained by the author(s), with first publication rights granted to the journal.

This is an open-access article distributed under the terms and conditions of the Creative Commons Attribution license (http://creativecommons.org/licenses/by/3.0/). 